\title{
Evaluation of Optimum Protein Requirement for Indian Spiny Loach (Lepidocephalus thermalis)
}

\author{
M. Renuhadevi ${ }^{1 *}$, B. Ahilan ${ }^{1}$, C.B.T. Rajagopalsamy², P. Padmavathy ${ }^{3}$, \\ I. Jegan Michael Andro Jeevagan ${ }^{1}$ and E. Prabu ${ }^{1}$
}

\author{
${ }^{1}$ Department of Aquaculture, ${ }^{2}$ Department of Fish Nutrition and Feed Technology, \\ ${ }^{3}$ Department of Aquatic Environment Management, Fisheries College and Research Institute, \\ Tamil Nadu Fisheries University, Thoothukudi - 628008, Tamil Nadu, India
}

*Corresponding author

\section{Keywords \\ Indian spiny loach, Protein feed, PER- Protein Efficiency Ratio, SGR- \\ Specific Growth Rate}

Article Info

Accepted:

12 June 2019

Available Online:

10 July 2019

\section{A B S T R A C T}

A 90 days growth trial was conducted to evaluate optimum protein requirement for Indian spiny loach (Lepidocephalus thermalis). Five different protein feeds viz., 20\%, 25\%, 30\%, 35\%, and $40 \%$ were prepared as experimental diets. This feeding trial was conducted in $40 \mathrm{~L}$ plastic troughs in triplicates using loaches with an average weight of $1.28 \mathrm{~g}-1.55 \mathrm{~g}$. During the experimental period, water quality parameters were measured and recorded daily. The mean value of water temperature, $\mathrm{pH}$, dissolved oxygen, ammonia$\mathrm{N}$, nitrite- $\mathrm{N}$, nitrate- $\mathrm{N}$, hardness, alkalinity in the experimental system were 23.5-26.3 ${ }^{\circ} \mathrm{C}, 8.5-8.7,5-6 \mathrm{ppm}, 0.01 \mathrm{ppm}, 0.05 \mathrm{ppm}, 10 \mathrm{ppm}, 650 \mathrm{ppm}, 165$ ppm respectively. Among the experimental diets $35 \%$ protein diet yielded the best result in terms of average body weight gain, PER, SGR and ADG. The mean body weight gain recorded in the $35 \%$ protein diet was $0.67 \pm 0.008 \mathrm{~g}$. In this study, $35 \%$ protein feed performed well in terms of growth rate and PER hence it is recommended that the optimum protein requirement for the better growth of Indian spiny loach (Lepidocephalus thermalis) is $35 \%$.

\section{Introduction}

Aquaculture plays an important role in global food security and employment provision. It is the fastest growing food producing sector. Stagnating marine capture yield has intensified aquaculture which helps to bridge the demand - supply gap (FAO, 2010). Aquaculture is presently looked upon as one of the greatest potential to meet the growing demand for aquatic food and it accounts for almost $50 \%$ of the world's food fish 
production (FAO, 2014). Lepidocephalus thermalis, a cobitid fish, inhabiting a wide variety of Habitats Rivers where the current are not strong, is commonly occurring loach of the Kerala state, lying in the extreme southwest of peninsular India (Kumari and Nair, 1979). Spined loach feed mostly from post-dusk to dawn and achieved maximum gut fullness in the morning. This nocturnal feeding pattern was consistent throughout all sampling occasions, but there was some discrepancy concerning 12.00 hours in spring and summer. Due to this, early morning activity cannot be excluded. Prey selection indices indicated that spined loach preferentially consumed some small size chironomids: Tanytarsus, Cladotanytarsus, Dicrotendipes and avoided larger ones (Glyptotendipes, Stictochironomus) (Marszal et al., 2004). They eat in a very unusual way using a filtration apparatus with sticky zones in the pharyngeal cavity (Caleta et al., 2015)

\section{Materials and Methods}

\section{Experimental fish}

The experimental fish (L. thermalis) were procured from Chola fish farm, Thanjavur, Tamil Nadu. The average weight fish is $1.25 \mathrm{~g}$ - 1.58g. The experimental fishes were acclimatized for the period of 20 days in the FRP tanks. During the acclimatization period, the loaches were fed with commercial pellet feed.

\section{Experimental set up}

The experimental setup comprised of 5 sets of treatments and each treatment has triplicates. Before starting the experiment, the troughs were washed with soap oil cleaned well with freshwater, they were dried under sunlight. Freshwater was filled in the troughs up to $3 / 4$ of its volume. All the troughs were provided with proper aeration facility.

\section{Preparation of feed}

The major ingredients used for the preparation of feed were soyabean meal, fish meal and shrimp head meal. These major ingredients were mixed in the feed at different concentration, with different protein levels viz., $20 \%, 25 \%, 30 \%, 35 \%$, and $40 \%$. All the ingredients and feed additives (except vitamin and mineral mixture) were mixed well as per the ratio and made it as ball and cooked in a pressure cooker for 10-15 minutes. Even distribution of additives was ensured by vigorous kneading. The cooked paste was cooled and vitamin and mineral mixture was added. Then each dough was pelletized separately by using the manual pelletizer. Each pelletized feeds were dried separately under the sun and stored in different airtight containers for the experiment (Table 1).

\section{Proximate composition of experimental feed}

The proximate composition of the test diets were analysed in animal feed analytical and quality assurance laboratory, Namakkal, Tamil Nadu, India (Table 3).

\section{Stocking}

The fishes weighing between $1.25 \mathrm{~g}$ to $1.58 \mathrm{~g}$ were stocked at 10 numbers per trough.

\section{Feeding}

The experimental fishes were fed with experimental feed. The fishes were fed ad libitum twice a day.

\section{Water quality parameters}

During the experimental period, water quality parameters such as Temperature, Dissolved oxygen, $\mathrm{pH}$ and Total alkalinity were measured and recorded daily (Table 3 ). 


\section{Sampling}

The sampling was carried out once in 15 days. The bio growth parameter like weight gain per day, specific growth rate were calculated by using the data gained during the experimental period.

\section{Statistical analysis}

The statistical analysis of different growth parameters was analysed by using one way analysis of variance and significance differences between treatments was assessed by Duncan multiple range test (Duncan, 1995). The level of significance was accepted at 5\% level. All statistical analyses were performed using SPSS, Release 22, software (SPSS Inc., USA).

\section{Results and Discussion}

The comparative growth performance of Indian Spiny Loach (Lepidocephalus thermalis) fed with different protein diets were given in Table 4.

The Specific growth rate observed in all the treatments at the descending order are 0.35 (35\%), 0.15 (40\%), 0.15 (25\%), 0.14 (30\%) and $0.05(20 \%)$

\section{Food conversion ratio (FCR)}

The Food conversion ratio of loach in all treatment groups recorded at the end of the experiment showed a wide difference among the different treatment groups as shown in Table 4. T5 (1.08 \pm 0.025$)$ showed better FCR among all the experimental diets.

\section{Feed Efficiency Ratio (FER)}

The Feed efficiency ratio of loach in all treatment groups recorded at the end of the experiment is presented in Table 4. It can be seen that the highest Feed Efficiency Ratio was found in T5 $(0.92 \pm 0.02)$ followed by T2 $(0.90 \pm 0.01)$.

\section{Protein Efficiency Ratio (PER)}

The Protein Efficiency Ratio of loach in all treatment groups recorded at the end of the experiment showed a wide difference among the different treatment groups as shown in Table 4. The highest Protein Efficiency Ratio of loach was attained in T4 $(0.281 \pm 0.01 \mathrm{~g})$, followed by T5 $(0.143 \pm 0.00 \mathrm{~g})$. The lowest Protein Efficiency Ratio was obtained in T1 $(0.062 \pm 0.00 \mathrm{~g}) .35 \%$ protein feed performed well in terms of growth rate and Protein Efficiency Ratio hence it is recommended that the optimum protein requirement for the better growth of Indian spiny loach (Lepidocephalus thermalis) is $35 \%$.

Loaches are mainly substrate feeders and they relish on phytoplankton such as diatoms and desmids and crustaceans such as daphnia and ostracods (Keskar et al., 2014). Fine-grained substrata are particularly favoured by spined loach (Robotham, 1978; Slavık et al., 2000). Spined loach fed mostly from post-dusk to dawn and achieved maximum gut fullness in the morning. This nocturnal feeding pattern was consistent throughout all sampling occasions (Marszal et al., 2004).

Although these Spiny loaches were fed with the laboratory feed, the amount of feed intake was less since they were not used to such feeds (Sundarabarathy et al., 2001). In the present study also the growth rate of the fishes were generally lower may be because of the above said reason.

The low protein tried in the experiment was $20 \%$ and the high protein tried was $40 \%$. In the low protein diet i.e., 20\% the mean weight gain observed was $0.14 \mathrm{~g}$ which was very less when compared to all other treatments. 
Table.1 Composition of experimental diets

\begin{tabular}{|c|c|c|c|c|c|c|}
\hline \multirow[t]{2}{*}{ SI. No } & \multirow[t]{2}{*}{ Ingredients } & \multicolumn{5}{|c|}{ Percentage of inclusion } \\
\hline & & $\begin{array}{c}20 \% \\
\text { (T1) }\end{array}$ & $\begin{array}{l}25 \% \\
\text { (T2) }\end{array}$ & $\begin{array}{l}30 \% \\
\text { (T3) }\end{array}$ & $\begin{array}{l}35 \% \\
\text { (T4) }\end{array}$ & $\begin{array}{l}40 \% \\
\text { (T5) }\end{array}$ \\
\hline 1 & Soyabean meal & 11 & 12 & 13 & 18 & 21 \\
\hline 2 & Fish meal & 10 & 15 & 21 & 24 & 26 \\
\hline 3 & Shrimp head meal & 8 & 11 & 12 & 13 & 19 \\
\hline 4 & Rice bran & 38 & 30 & 25 & 23 & 14 \\
\hline 5 & Tapioca flour & 28.3 & 27.3 & 24.3 & 17.3 & 15.3 \\
\hline 6 & $\begin{array}{l}\text { Monocalcium } \\
\text { phosphate }\end{array}$ & 1.7 & 1.7 & 1.7 & 1.7 & 1.7 \\
\hline 7 & Fish oil & 1 & 1 & 1 & 1 & 1 \\
\hline 8 & Salt & 1 & 1 & 1 & 1 & 1 \\
\hline 9 & Vitamin premix & 0.5 & 0.5 & 0.5 & 0.5 & 0.5 \\
\hline 10 & Mineral premix & 0.5 & 0.5 & 0.5 & 0.5 & 0.5 \\
\hline
\end{tabular}

Table.2 Water quality parameters

\begin{tabular}{|c|l|l|}
\hline S. No & \multicolumn{1}{|c|}{ Parameters } & \multicolumn{1}{c|}{ Range } \\
\hline $\mathbf{1}$ & Temperature & $23.5-26.3^{\circ} \mathrm{C}$ \\
\hline $\mathbf{2}$ & Dissolved Oxygen & $5-6 \mathrm{ppm}$ \\
\hline $\mathbf{3}$ & PH & $8.5-8.7$ \\
\hline $\mathbf{5}$ & Ammonia & $0.01 \mathrm{ppm}$ \\
\hline $\mathbf{6}$ & Nitrite & $0.05 \mathrm{ppm}$ \\
\hline $\mathbf{7}$ & Nitrate & $10 \mathrm{ppm}$ \\
\hline $\mathbf{8}$ & Hardness & $650 \mathrm{ppm}$ \\
\hline $\mathbf{9}$ & Alkalinity & $165 \mathrm{ppm}$ \\
\hline
\end{tabular}


Table.3 Proximate composition of experimental diets

\begin{tabular}{|c|c|c|c|c|c|c|c|}
\hline SI. No & Diet & Moisture & Protein & Fibre & Fat & Ash & Gross energy \\
\hline $\mathbf{1}$ & T1 (20\%) & $9.38 \%$ & $20.37 \%$ & $11.87 \%$ & $6.12 \%$ & $12.08 \%$ & $3828 \mathrm{kcal} / \mathrm{kg}$ \\
\hline $\mathbf{2}$ & T2 (25\%) & $10.25 \%$ & $25.16 \%$ & $11.10 \%$ & $5.45 \%$ & $12.23 \%$ \\
\hline $\mathbf{3}$ & T3 (30\%) & $11.54 \%$ & $30.13 \%$ & $8.82 \%$ & $5.01 \%$ & $12.10 \%$ \\
\hline $\mathbf{4}$ & T4 (35\%) & $10.43 \%$ & $35.12 \%$ & $7.77 \%$ & $5.52 \%$ & $12.92 \%$ & $3870 \mathrm{kcal} / \mathrm{kg}$ \\
\hline $\mathbf{5}$ & T5 (40\%) & $10.28 \%$ & $40.08 \%$ & $6.91 \%$ & $4.93 \%$ & $13.21 \%$ \\
\hline
\end{tabular}

Table.4 Comparative growth performance of Indian Spiny Loach fed with different protein diets

\begin{tabular}{|c|c|c|c|c|c|c|c|c|c|c|c|c|}
\hline Diet & $\begin{array}{c}\text { Initial wt } \\
\text { (g) }\end{array}$ & $\begin{array}{l}\text { Final wt } \\
\text { (g) }\end{array}$ & $\begin{array}{c}\text { Mean wt } \\
\text { gain }(g)\end{array}$ & Survival & $\begin{array}{l}\text { Biomass } \\
\text { gain }\end{array}$ & $\begin{array}{c}\text { Total } \\
\text { Biomass }\end{array}$ & $\begin{array}{c}\text { Total } \\
\text { feed } \\
\text { intake }\end{array}$ & FCR & FER & PER & SGR & ADG \\
\hline $\begin{array}{c}1 \\
(20 \%)\end{array}$ & $1.40 \pm .014$ & $\begin{array}{c}1.55 \\
\pm 0.01^{\mathrm{a}}\end{array}$ & $\begin{array}{c}0.14 \pm \\
0.02^{\mathrm{a}}\end{array}$ & $\begin{array}{l}8.66 \pm \\
0.33^{\mathrm{ab}}\end{array}$ & $\begin{array}{l}1.25 \\
\pm 0.09^{\mathrm{a}}\end{array}$ & $\begin{array}{l}13.46 \pm \\
0.66^{\mathrm{a}}\end{array}$ & $\begin{array}{l}15.00 \\
\pm 0.57^{\mathrm{a}}\end{array}$ & $\begin{array}{l}1.11 \pm \\
0.026^{\mathrm{ab}}\end{array}$ & $\begin{array}{l}0.89 \\
\pm 0.02^{\mathrm{ab}}\end{array}$ & $0.062 \pm 0.00^{\mathrm{a}}$ & $\begin{array}{l}0.05 \\
\pm 0.003^{\mathrm{a}}\end{array}$ & $\begin{array}{l}0.001 \pm \\
0.00^{\mathrm{a}}\end{array}$ \\
\hline $\begin{array}{c}2 \\
(25 \%)\end{array}$ & $1.34 \pm 0.065$ & $\begin{array}{l}1.66 \\
\pm 0.06^{\mathrm{ab}}\end{array}$ & $\begin{array}{l}0.27 \pm \\
0.005^{b}\end{array}$ & $8.0 \pm 0.57^{\mathrm{a}}$ & $\begin{array}{l}2.19 \\
\pm 0.22^{b}\end{array}$ & $\begin{array}{l}12.91 \pm \\
1.06^{\mathrm{a}}\end{array}$ & $\begin{array}{l}14.33 \pm \\
1.20^{\mathrm{a}}\end{array}$ & $\begin{array}{l}1.11 \pm \\
0.017^{\mathrm{ab}}\end{array}$ & $\begin{array}{l}0.90 \\
\pm 0.01^{a b}\end{array}$ & $\begin{array}{l}0.109 \\
\pm 0.01^{\mathrm{b}}\end{array}$ & $\begin{array}{l}0.15 \\
\pm 0.015^{b}\end{array}$ & $\begin{array}{c}0.003 \pm \\
0.00^{\mathrm{b}}\end{array}$ \\
\hline $\begin{array}{c}3 \\
(30 \%)\end{array}$ & $1.34 \pm 0.40$ & $\begin{array}{l}1.61 \\
\pm 0.04^{\mathrm{ab}}\end{array}$ & $\begin{array}{c}0.26 \\
\pm 0.008^{\mathrm{b}}\end{array}$ & $\begin{array}{l}8.0 \pm 0.00 \\
\mathrm{a}\end{array}$ & $\begin{array}{l}2.13 \\
\pm 0.07^{b}\end{array}$ & $\begin{array}{l}12.85 \\
\pm 0.33^{\mathrm{a}}\end{array}$ & $\begin{array}{l}15.66 . \pm \\
0.33^{\text {ab }}\end{array}$ & $\begin{array}{l}1.21 \\
\pm 0.031^{b}\end{array}$ & $\begin{array}{l}0.82 \\
\pm 0.02^{\mathrm{a}}\end{array}$ & $\begin{array}{c}0.106 \\
\pm 0.00^{\mathrm{b}}\end{array}$ & $\begin{array}{c}0.14 \\
\pm 0.009^{\mathrm{b}}\end{array}$ & $\begin{array}{c}0.003 \pm \\
0.00^{\mathrm{b}}\end{array}$ \\
\hline $\begin{array}{c}4 \\
(35 \%)\end{array}$ & $1.41 \pm 0.03$ & $\begin{array}{c}2.09 \pm \\
0.01^{\mathrm{c}}\end{array}$ & $\begin{array}{c}0.67 \\
\pm 0.008^{c}\end{array}$ & $\begin{array}{l}8.33 \pm \\
0.33^{a}\end{array}$ & $\begin{array}{l}5.62 \\
\pm 0.30^{d}\end{array}$ & $\begin{array}{l}17.41 \\
\pm 0.61^{b}\end{array}$ & $\begin{array}{l}21.00 \pm \\
0.57^{c}\end{array}$ & $\begin{array}{l}1.21 \pm \\
0.069^{\mathrm{ab}}\end{array}$ & $\begin{array}{l}0.83 \\
\pm 0.05^{\text {ab }}\end{array}$ & $0.281 \pm 0.01^{d}$ & $\begin{array}{c}0.35 \\
\pm 0.032^{c}\end{array}$ & $\begin{array}{l}0.007 \pm \\
0.00^{c}\end{array}$ \\
\hline $\begin{array}{c}5 \\
(40 \%)\end{array}$ & $1.38 \pm 0.00$ & $\begin{array}{l}1.68 \pm \\
0.00^{\mathrm{b}}\end{array}$ & $\begin{array}{l}0.29 \pm \\
0.007^{b}\end{array}$ & $\begin{array}{l}9.66 \pm \\
0.33^{b}\end{array}$ & $\begin{array}{l}2.87 \\
\pm 0.14^{\mathrm{c}}\end{array}$ & $\begin{array}{l}16.27 \pm \\
0.55^{\mathrm{b}}\end{array}$ & $\begin{array}{l}17.66 \pm \\
0.88^{b}\end{array}$ & $\begin{array}{c}1.08 \\
\pm 0.025^{\mathrm{a}}\end{array}$ & $\begin{array}{l}0.92 \pm \\
0.02^{\mathrm{b}}\end{array}$ & $\begin{array}{c}0.143 \pm \\
0.00^{\mathrm{c}}\end{array}$ & $\begin{array}{l}0.15 \\
\pm 0.005^{\mathrm{b}}\end{array}$ & $\begin{array}{c}0.003 \pm \\
0.00^{\mathrm{b}}\end{array}$ \\
\hline
\end{tabular}


The specific growth rate in the treatment was calculated to be $0.05 \mathrm{~g}$ and average daily growth was $0.02 \mathrm{~g}$.

In the $25 \%$ protein diet the mean weight gain was recorded to be $0.27 \mathrm{~g}$ and the specific growth rate was calculated to be $0.15 \mathrm{~g}$. The average daily growth was calculated to be $0.003 \mathrm{~g}$. The results were somewhat better than $20 \%$ protein diet.

For the fishes fed with $30 \%$ protein diet the mean weight gain was observed to be $0.26 \mathrm{~g}$ and the specific growth rate was calculated to be $0.14 \mathrm{~g}$. It is observed that there is no significant difference between $25 \%$ and $30 \%$ protein diet. The results were almost similar in terms of mean weight gain and specific growth rate as observed by Swamy, 2004. Kumar et al., (2011) found that diet with protein content of $25 \%$ had better impact than other diets on growth of stunted fingerlings of mrigal and rohu reared in manured ponds.

With regard to the fishes fed with $35 \%$ protein diet the mean weight gain of $0.67 \mathrm{~g}$ was observed which was superior in comparing all other treatments. The mean weight gain was 4 times higher when compared to $20 \%$ diet fed fishes and two times higher in $25 \%$ and $30 \%$ fed fishes. The specific growth rate calculated in the $35 \%$ protein diet was $0.35 \mathrm{~g}$ and the average daily growth was $0.007 \mathrm{~g}$ which was also superior when compared to all other treatments.

In the $40 \%$ protein diet the mean weight gain recorded was $0.29 \mathrm{~g}$ which was very low than the $35 \%$ protein diet similarly the specific growth rate and average daily growth was also very low when compared to $35 \%$ protein diet. Crude protein levels ranging from 30 to 38 percent appear to satisfy the fish optimally. This level has been determined by using semipurified diets containing a single high-quality protein source (casein, whole-egg protein or fishmeal). When the diet contains sufficient digestible energy, the optimal protein level can be effectively kept at 30-35 percent (Watanabe, 1982).The optimum protein requirement for fingerlings has also been reported at 40 percent (Swamy and Mohanty, 1990; Satapathy et al., 2003).

Common carp growth was higher when fed higher protein containing feed $(35.2 \%)$ and lower growth when fed without having fish meal. The fish growth containing lower protein feed $(27.1 \%)$ the commercial cattle feed was better than the fish fed having fish meal but contained higher protein level (30\%) (Mohapatra and Patra, 2014).

Hence it may be concluded that $35 \%$ protein diet is good for the better growth of Indian spiny loach (Lepidocephalus thermalis). The $30 \%$ dietary protein was the optimum level for maximum growth of the young bighead carp. This is a relatively low level compared with the protein requirements reported for other carp species, particularly common carp fry, 45\% (Sen et al., 1978) and fingerlings, 38\% (Ogino and Saito, 1970); grass carp fry, 4 1-43\% (Dabrowski, 1977); rohu fry, 45\% (Sen et al., 1978); and catla fry, 47\% (Singh and Bhanot, 1988). Mazid et al., (1987) studied nutritional requirements of Labeo rohita and commented that major carp fed with $38 \%$ gross protein showed better growth in terms of weight gain.

The Food conversion ratio of loach in all treatment groups recorded at the end of the experiment showed a wide difference among the different treatment groups. T5 (1.08 \pm 0.025) showed better FCR among all the experimental diets. Dars et al., (2010) observed highest growth and production in experimental fish fed with feed B (35\% gross protein) followed by feed $\mathrm{C}(40 \%$ gross protein).The FCR of catla fingerlings calculated by Dars et al., (2010) was 3.90 
when fed with diet containing $35 \%$ protein level. It can be seen that the highest Feed Efficiency Ratio was found in T5 (0.92 \pm $0.02)$ followed by $\mathrm{T} 2(0.90 \pm 0.01)$.

Protein levels on grow out diets often approach or exceed $40 \%$ crude protein, while maintenance diets may contain as little as 25$35 \%$ (Houlihan et al., 2001). The Protein Efficiency Ratio of loach in all treatment groups recorded at the end of the experiment showed a wide difference among the different treatment groups. The highest Protein Efficiency Ratio of loach was attained in T4 $(0.281 \pm 0.01 \mathrm{~g})$, which resulted in the highest mean weight gain in fishes fed with $35 \%$ protein diet.

In the present study $35 \%$ protein feed performed well in terms of growth rate hence it is recommended that the optimum protein requirement for the better growth of Indian spiny loach (Lepidocephalus thermalis) is $35 \%$.

\section{Acknowledgement}

We gratefully acknowledge the funding support by the Tamilnadu Fisheries University, Nagapattinam, Tamil Nadu.

\section{References}

Caleta, M., Buj, I., Mrakovčić, M., Mustafić, P., Zanella, D., Marčić, Z., Duplić, A., Mihinjač, T. and Katavić, I., 2015. Endemic fishes of Croatia. Communities. Cyprinidae. Bijdragen tot de Dierkunde, pp.33-35.

Dabrowski, K., 1977. Protein requirements of grass carp fry Ctenopharyngodon idella Val. Aquaculture, 12, pp.63-73.

Dars, B.A., Narejo, N.T., Dayo, A., Lashari, P.K., Laghari, M.Y. and Waryani, B., 2010. Effect of different protein on growth and survival of Catla catla
(Hamilton) reared in glass aquaria. Sindh University Research Journal-SURJ (Science Series), 42(1).

Duncan, D.B. 1995. Multiple range and multiple (F) test. Biometrics, 11: 1-42.

Food and Agriculture Organisation. 2010. The State of World Fisheries and Aquaculture. FAO. Rome.

Food and Agriculture Organisation. 2014. The State of World Fisheries and Aquaculture. FAO. Rome.

Houlihan, D., T. Bouiard and M. Jobling, 2001. Food intake in fish. Lowa State University Press, Blackwell Sci. Ltd., pp. 418.

Keskar, A., Padhye, A. and Dahanukar, N., 2014. Fighting against all odds: the struggle for existence among hill stream loaches of northern Western Ghats. Min-Newsletter of FFSG, 2, pp. 25-29.

Kumar, R. V., Ramesh, K. S., Patil, P., Kumar, N. B. T., Joseph., Manissery, J. K. 2011. Dietary protein requirement of stunted fingerlings of rohu, Labeo rohita (Hamilton) during grow-out stage. Indian J. Fish. 58(4), 49-53.

Kumari, S.D. and Nair, N.B., 1979. Oogenesis in a tropical loach Lepidocephalus thermalis (cuv. and val.) (India). Proceedings of Indian Academy of Sciences (India).

Marszal, L., Grzybkowska, M., Przybylski, M. and Valladolid, M., 2004. Feeding activity of spined loach Cobitis sp. in Lake Lucien, Poland. Folia biologicakrakow, 51, pp. 159-165.

Mazid, M. A., M. A. Rahman, S. Gheyasuddin, M. A. Hossain and Rashid, M. B., 1987. Nutritional requirements of major carp-1. Optimum level of dietary protein for Labeo rohita. Bangladesh J. Fish., 10(2), Pp. 75-82.

Mohanty, S.N., Swamy, D.N. and Tripathi, S.D. 1990. Protein utilization in Indian 
major carp fry, Catla catla, Labeo rohita and Cirhinus mrigala fed four protein diets. Journal of Aquaculture in the Tropics, 5, 173-179.

Mohapatra, S. B., and Patra, A.K., 2014. Growth response of common carp (Cyprinus carpio) to different feed ingredients incorporate diets. Advances in Applied Science Research, 5(1), 169173.

Ogino, C. and Saito, K., 1970. Protein nutrition in fish. 1. The utilization of dietary protein by young carp. Bulletin of the Japanese Society of Scientific Fisheries, 36(3), 250-254.

Regan, C.T., 1911. The classification of teleostean fishes of the order Ostariophysi. I. Cyprinoidae. Ann. Mag. Nat. Hist., 8(8), 13-32.

Robotham, P.W.J., 1978. Some factors influencing the microdistribution of a population of spined loach, Cobitis taenia (L.). Hydrobiologia, 61(2), 161167.

Satapathy, B.B., Mukherjee, D. and Ray, A.K. 2003. Effects of dietary proten and lipid levels on growth, feed conversion and body composition in rohu, Labeorohita (Hamilton), fingerlings. Aquaculture Nutrition, 9, 17-24.

Sen, R.R., Rao, N.G.S., Ghosh, G.R. and Rout, M., 1978. Observations on the protein and carbohydrate requirements of carps. Aquaculture, 13, 245-255.

Singh, B.N. and Bhanot, K.K., 1988. Protein requirement of the fry of Catla catla (Ham.). In: M. Mohan Joseph (Editor). The First Indian Fisheries Forum, Proceedings. Asian Fisheries Society, Indian Branch, Mangalore, pp. 77-78.

Slavík, O., Mattas, D., Jiřinec, P., Bartoš, L., and Rebec. J., 2000. Substratum selection by different sizes of spined loach Cobitis sp. Folia Zool, 49(1), 167172.

Sundarabarathy, T.V., Edirisinghe, U., Dematawewa, C.M.B. and Nandasena, K.G., 2001. Morphology and some biological aspects of common spiny or lesser loach (Lepidocephalichthys thermalis) and banded mountain or spotted loach (Schistura notostigma) of Sri Lanka. Tropical Agricultural Research 13: 411-429.

Swamy, A. V., 2004. Growth response of stunted fingerlings of Indian major carp, Cirrhinus mrigala (Ham.) to varied protein levels during grow-out phase. M. F. Sc. Thesis submitted to University of Agricultural Sciences, Bangalore.

Swamy, D.N. and Mohanty, S.N., 1990. Response of Rohu (Labeorohita Ham) fingerlings to diets of different protein contents. Journal of Zoological Research, 3(2), 121-125.

Watanabe, T., 1982. Lipid nutrition in fish. Comp. Biochem. Physiol., Part A, 73, 3-15.

\section{How to cite this article:}

Renuhadevi, M., B. Ahilan, C.B.T. Rajagopalsamy, P. Padmavathy, I. Jegan Michael Andro Jeevagan and Prabu, E. 2019. Evaluation of Optimum Protein Requirement for Indian Spiny Loach (Lepidocephalus thermalis). Int.J.Curr.Microbiol.App.Sci. 8(07): 1650-1657. doi: https://doi.org/10.20546/ijcmas.2019.807.196 